\title{
Peter Kürsteiner and Christian Klug 2018. Fossilien im Alpstein. Kreide und Eozän der Nordostschweiz. Appenzeller Verlag, 372 pp
}

\author{
Daniel Marty ${ }^{1}$ (D)
}

Received: 24 May 2018 / Accepted: 4 June 2018/Published online: 8 June 2018

(C) Akademie der Naturwissenschaften Schweiz (SCNAT) 2018

The book "Fossilien im Alpstein", written in German, is an outstandingly well-written and well-illustrated (full colour) comprehensive book about Cretaceous and Eocene fossils of the Alpstein region of Northeastern Switzerland. This hardcover book comes in a larger format than A4, has 372 pages and is published by the Appenzeller Verlag. Amongst others, this book has benefited from financial support by the Swiss Palaeontological Society, the Swiss Geological Society and the Swiss Academy of Sciences.

This book was compiled and edited by Peter Kürsteiner and Christian Klug, and it comprises contributions of many other researchers that have worked or still working in the study area. First, the book addresses general topics that are relevant to understand the importance and distribution of the many fossil groups that can be found in the Alpstein region and that are described later on in the book. Amongst these topics are the geology of the Alpstein including tectonics and lithostratigraphy (by Soom et al.); a general introduction to fossils with topics such as formation, taphonomy, preparation and museography (by Kürsteiner); history of palaeontological research in the Alpstein since the eighteenth century (by Kürsteiner), palaeoecology and palaeogeography (by Tschanz); and phylogeny and systematics (by Klug). All these chapters include many useful (comprehensive) figures, outcrop photographs, tables and agile life reconstructions (e.g. by Scheffold and Klug; Fig. 1).

A comprehensive catalogue of the fossils of the Alpstein that is subdivided into chapters dealing with the major fossil groups follows this. Various specialists that have worked on these groups wrote the according chapters: stromatolites, microbial mats and Plantae (by Bollinger),

Editorial Handling: C. Klug.

Daniel Marty

martydaniel@hotmail.com

1 Naturhistorisches Museum Basel, Augustinergasse 2, 4051 Basel, Switzerland
Rhodolithes (Rasser), Foraminifera including nummulites (by Goldbeck), Porifera (Furrer), Anthozoa with a remarkably high diversity (Baron-Szabo and Furrer), Bryozoa (Hara and Furrer), Serpulidae (Jäger), Gastropoda (one of the more frequent groups) and Scaphopoda (Kollmann), Bivalvia including epifaunal forms with the shell preserved as well as infaunal forms (Stössel), Nautiloidea and Ammonoidea, the latter of which possibly is (besides the corals) the most diverse and best-studied group of the Alpstein and includes many heteromorph forms (Tajika et al.), Belemnitida (Klug and Tajika), Brachiopoda, a diverse group on which Sulser has worked and published over many years (Sulser and Kürsteiner), Decapoda (Furrer), Crinoidea including isocrinids, apiocrinids and roveacrinids (Hess ${ }^{\dagger}$ et al.); Echinoidea with regular and irregular sea urchins (by Hostettler and Menkveld-Gfeller); Chondrichthyes with quite a large range of different shark teeth (Kindlimann), Osteichthyes (Bürgin), Reptilia describing some rare rests of ichthyosaurs (Scheyer), and last but not least trace fossils (Furrer).

The book ends with an appendix including a list of figures, illustrations and authors; an index of the collections and an equally exhaustive and useful alphabetic index listing all (latin) fossil names.

I knew about the fossil richness of the Säntis and Alpstein region, but was surprised by how much richer and diverse the fossil record of this region actually is than I had previously assumed. For this reason, this book also constitutes a good reference for researchers and amateur collectors who work or who are interested in Cretaceous and Eocene fossils of the Alpine realm in general.

It is interesting to mention that recently several papers on the palaeontology of the Alpstein region have been published in the Swiss Journal of Palaeontology, and two papers by Tajika and colleagues are published in this issue (Tajika et al. 2018a, b). This shows that the research area still is a hotspot for palaeontological research and underlines the importance and the utility of such a book. 


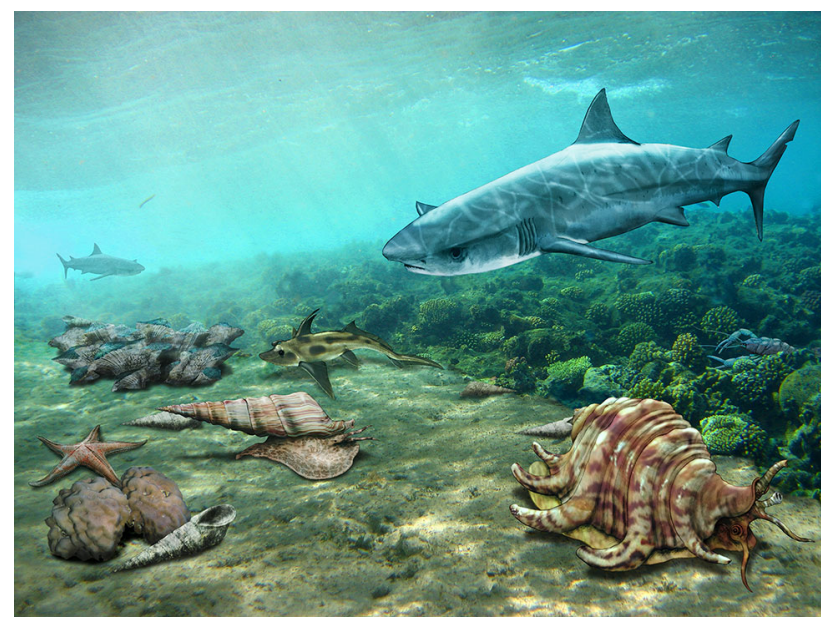

Fig. 1 Reconstruction of the marine palaeoenvironment during the Early Aptian (Oberer Schrattenkalk) by Scheffold and Klug (Kürsteiner and Klug 2018, Fig. 21 on p. 35) (Reproduced with permission from (C) Appenzeller Verlag)
To conclude, in the first instance, this book is rather addressing collectors and a broader interested public than the scientific community. However, because the fossil part of the book is so comprehensive and well illustrated it is certainly a must have for every palaeontologist and geologist working in the Alpstein region or on Cretaceous and Eocene faunas of the Alpine realm in general.

\section{References}

Tajika, A., Kürsteiner, P., \& Klug, C. (2018a). Ecological disparity is more susceptible to environmental changes than familial taxonomic richness during the Cretaceous in the Alpstein region (northeastern Switzerland). Swiss J Palaeontol. https://doi.org/ 10.1007/s13358-017-0140-y.

Tajika, A., Tschanz, K., \& Klug, C. (2018b). New Albian ammonite faunas from Semelenberg (Alpstein, Switzerland) and their palaeoecology. Swiss J Palaeontol. https://doi.org/10.1007/ s13358-018-0152-2. 